\title{
EXPERIMENTAL STUDY OF CONCRETE PREPARED BY EGGSHELL POWDER AND COPPER SLAG
}

\author{
NIPUN BHARDWAJ ${ }^{1}$ \& RAJEEV KUMAR ${ }^{2}$ \\ ${ }^{I}$ M E Scholar, Department of Civil Engineering, Chandigarh University, Mohali, Punjab, India \\ ${ }^{2}$ Assistant Professor, Department of Civil Engineering, Chandigarh University, Mohali, Punjab, India
}

\begin{abstract}
This paper discusses the work done on concrete by the replacement of cement with eggshell powder and fine aggregate replaced by copper slag. The fresh properties in terms of the slump and hardened properties in terms of flexural strength, split tensile strength, and compressive strength is been studied. It is seen in the study that replacement of cement can be done by eggshell powder up-to $15 \%$ but optimum strength can be taken at 10\%. On the same hand fine aggregate can be replaced upto $40 \%$ by copper slag but optimum strength will be at $30 \%$. As the replacement of eggshell powder increases than slump starts decreasing but in the case of coppers lag the slump starts increasing at its varying percentages. The gain is strength is achieved using eggshell powder and copper slag in combination.

KEYWORDS: Egg Shell powder, Copper Slag, Slump, Mechanical Strength
\end{abstract}

Received: May 09, 2020; Accepted: Jun 29, 2020; Published: Jun 30, 2020; Paper Id.: IJMPERDJUN2020236

\section{INTRODUCTION}

Today the development needs rapid construction and industrialization which needs concrete in huge quantities which produces pollution. In huge quantities the waste is generated the generation of waste in India exceed more than 1 lakh metric tons per day. if we can use this pollution waste in the concrete it will help in the reduction of pollution and helps to regain the environmental strength.

Eggshell Powder: -Use of concrete creates emission of carbon dioxide, the use of eggshell powder can reduce this emission. Eggshell powder is a food waste which is very rich in calcium compound.[1] Eggshell is known as a smooth surface that is attractive thought about unpleasant eggshells cracks more without any problem. Most great quality eggshells from business layers contain roughly 2.2 grams of calcium as calcium carbonate. About $95 \%$ of the dry eggshell is calcium.

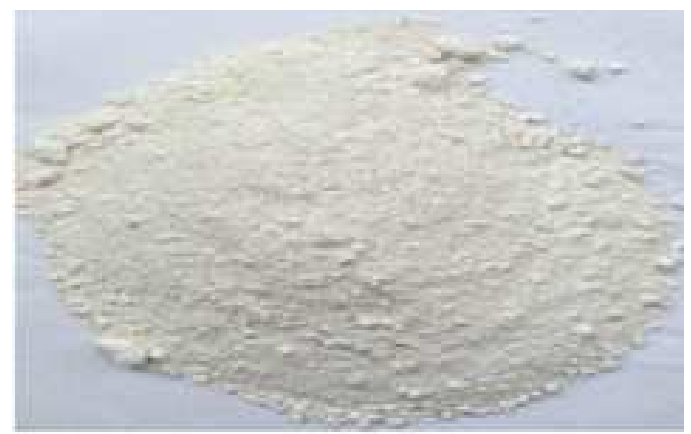

Figure 1: Crushed Eggshell Powder. 


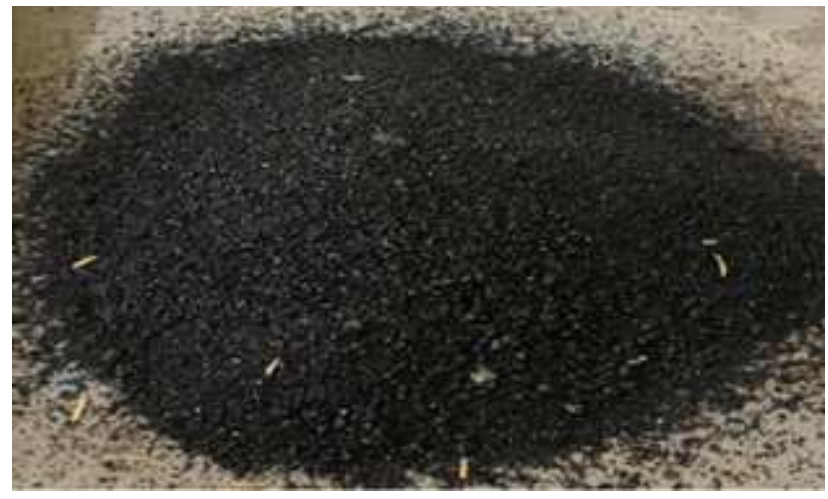

Figure 2: Copper Slag.

Copper Slag: - Copper slag is the by-product of copper industries i.e. after the refining of copper the by-product is copper slag. Every ton of copper will generate approximately 2.5 tons of copper slag.[2] use of copper slag can also increase the density up to $2755.6 \mathrm{Kg} / \mathrm{m}^{3}$. Copper slag is irregular, granular in nature, glassy and black and its properties are like the river sand. Copper slag can easily replace the fine aggregate in the concrete mix. [3] high toughness of copper slag contributes tothe increment of concrete mix. Copper slag is very rich in silica.

\section{LITERATURE REVIEW}

- Copper slag is the replacement of fine aggregate. Replacement of copper slag can be done up to $40 \%$ but optimum strength can be achieved at $30 \%$ replacement. Use of copper slag increases the mass density of the concrete.

- The use of eggshell powder can be found optimum at $15 \%$. It can be replaced by up to $20 \%$. It is found to be increasing strength of $8 \%$ at the replacement of $15 \%$ the fineness of eggshell is the reason for giving increment in the strength of concrete.

- Eggshells can also be used as the replacement of fine aggregate. Fine aggregate can be replaced by up to $30 \%$. During this study it is also seen that there is a huge difference between normal and controlled specimens. Eggshell cannot be used as $100 \%$ replacement of fine aggregate

- Studies about the concrete prepared copper slag. SEM, XRD and EDS analysis was done. And it is seen that the microstructure forms of calcium silicate hydrate layers under SEM analysis giving the concrete matrix a denser and homogenous structure. The maximum amount of silica was found in $20 \%$ copper slag SCC mix owing to a good pozzolanic reaction. A reduction in $\mathrm{Ca} / \mathrm{Si}$ ratio was observed in SCC mixes incorporating up to $40 \%$ copper slag in comparison to control SCC; Thus, defining the increased strength of the concrete matrix. However, the value of the $\mathrm{Ca} / \mathrm{Si}$ ratio was almost comparable after $40 \%$ slag replacement.

\section{EXPERIMENTAL METHODOLOGY}

In this experimental, 84 specimens for each test are being prepared i.e. 84 cubes for compressive strength, 84 beams for flexural strength, and 84 columns for split tensile strength of concrete is prepared. All the design of concrete and other mix proportions are taken in perspective of Indian standards [6]-[8].

The grade of concrete was M25 with a mixing ratio of 1:1:2. For the use of eggshell powder and copper slag the eggshell powder is heated up to $2400^{\circ} \mathrm{C}$ and then grounded and passed through 90 -micron sieve the quantity for one cube, one beam, and one column is given in Error! Reference source not found.. 
The cement was replaced with eggshell powder and fine aggregate was replaced with copper slag. this replacement was done under the fineness of the materials.

The material specifications are: -

- $\quad$ The specific gravity of cement: -3.3

- Initial and final setting time of cement: $-30 \mathrm{~min}$ and 580min.

- The fineness of cement: $-97.8 \%$

- The specific gravity of fine aggregate: -2.64

- The specific gravity of coarse aggregate: -2.7

- The fineness of fine aggregate: -3.2 (zone II)

- The fineness of coarse aggregate: - 8.1

- Dimension of cube: $-150 X 150 X 150$

- Dimension of beam: - 100X100X500

- Dimension of column: - 150X300

Table 1: Quantities of Concrete Mix for 1 Cube, 1 Beam and 1 Column

\begin{tabular}{|l|c|c|c|c|c|c|c|c|}
\hline \multirow{2}{*}{ Ratio } & \multirow{2}{*}{ Cement } & \multirow{2}{*}{ Fine Aggregate } & \multirow{2}{*}{ Coarse Aggregate } & \multirow{2}{*}{ Water } & \multicolumn{2}{c|}{ Egg Shell } & \multicolumn{2}{c|}{ Copper Slag } \\
\cline { 5 - 9 } & & & & & Percentage & in kg & Percentage & in kg \\
\hline E0C0 & 8 & 8 & 16 & 4 & 0 & 0 & 0 & 0 \\
\hline E5C0 & 7.6 & 8 & 16 & 4 & 5 & 0.4 & 0 & 0 \\
\hline E10C0 & 7.2 & 8 & 16 & 4 & 10 & 0.8 & 0 & 0 \\
\hline E15C0 & 6.8 & 8 & 16 & 4 & 15 & 1.2 & 0 & 0 \\
\hline E20C0 & 6.4 & 8 & 16 & 4 & 20 & 1.6 & 0 & 0 \\
\hline E10C5 & 7.2 & 7.6 & 16 & 4 & 10 & 0.8 & 5 & 0.4 \\
\hline E10C10 & 7.2 & 7.2 & 16 & 4 & 10 & 0.8 & 10 & 0.8 \\
\hline E10C15 & 7.2 & 6.8 & 16 & 4 & 10 & 0.8 & 15 & 1.2 \\
\hline E10C20 & 7.2 & 6.4 & 16 & 4 & 10 & 0.8 & 20 & 1.6 \\
\hline E10C25 & 7.2 & 6 & 16 & 4 & 10 & 0.8 & 25 & 2 \\
\hline E10C30 & 7.2 & 5.6 & 16 & 4 & 10 & 0.8 & 30 & 2.4 \\
\hline E10C35 & 7.2 & 5.2 & 16 & 4 & 10 & 0.8 & 35 & 2.8 \\
\hline E10C40 & 7.2 & 4.8 & 16 & 4 & 10 & 0.8 & 40 & 3.2 \\
\hline E10C45 & 7.2 & 4.4 & 16 & 4 & 10 & 0.8 & 45 & 3.6 \\
\hline
\end{tabular}

\section{RESULTS}

In this experimental study to check the properties of concrete slump test on fresh concrete and three strength test (compressive strength, flexural strength and split tensile strength) were done on hardened concrete All the test were done per Indian standards (i.e. IS 456:2000, 2000; IS 516:1959, 1959; IS 5816:1999, 1999).The following results were derived out after the specific test which is given in Error! Reference source not found..the formulas used for the test are

1. Compressive Strength $=\frac{\text { Appliad load in newon }}{\text { Area of concuct of wbe }} 2$. Split tensile strength $=\frac{2-l o a d}{\pi D L} 3$. flexural strongth $=\frac{\text { PL }}{b d^{2}}$ 
Slump: - It is seen that when we increase the percentage replacement of eggshells in concrete the slump starts decreasing but the rate is not so high but after $10 \%$ replacement of eggshell the rapid decrement was seen in the slump when copper slag replacement was done. Fall maybe because of the fineness of copper slag.

Compression: - The replacement of eggshell gives an increment in strength up to a certain limit after that this value starts decreasing. When fine aggregates are replaced by copper slag the value of compression strength starts increasing and it can be replacing up to 40 percent, but the optimum result was at $30 \%$ replacement.

Split Tensile Strength: - The split tensile strength is not the governing factor for the replacement by eggshell and copper slag because the fineness of eggshell and copper slag may increase the compressive capacity of concrete but unable to make increment of the split tensile strength of concrete. Rather this replacement makes a big decrement in the strength of concrete.

Flexural Strength - As previously stated and previous studies tell us that the is no change of flexural strength on using the eggshell powder in concrete, but the use of copper slag can make a positive increment in the flexural strength of concrete but that too for a small limit

Table 2: Results of Experimental Study

\begin{tabular}{|l|c|c|c|c|c|c|c|}
\hline & \multirow{2}{*}{ SLUMP } & \multicolumn{2}{c|}{ Compressive Strength } & \multicolumn{2}{c|}{ Flexural Strength } & \multicolumn{2}{c|}{ Spilt Tensile } \\
\cline { 3 - 8 } & & 7 DAYS & 28 DAYS & 7 DAYS & 28 DAYS & 7 DAYS & 28 SAYS \\
\hline E0C0 & 110 & 17.01 & 25.60 & 2.62 & 4.10 & 2.28 & 2.9 \\
\hline E5C0 & 108 & 19.2 & 28.8 & 2.65 & 4.10 & 2.16 & 2.8 \\
\hline E10C0 & 105 & 19.8 & 29.7 & 2.65 & 4.10 & 2.08 & 2.67 \\
\hline E15C0 & 103 & 17.3 & 25.95 & 2.65 & 4.15 & 2.07 & 2.45 \\
\hline E20C0 & 100 & 16.5 & 24.75 & 2.8 & 4.15 & 1.9 & 2.36 \\
\hline E10C5 & 98 & 22.3 & 31.2 & 2.6 & 4.10 & 2.1 & 2.7 \\
\hline E10C10 & 95 & 24.6 & 33.2 & 2.8 & 4.15 & 2.15 & 2.7 \\
\hline E10C15 & 90 & 26.3 & 36.1 & 2.8 & 4.15 & 2.6 & 2.8 \\
\hline E10C20 & 87 & 28.1 & 37.2 & 2.8 & 4.15 & 2.6 & 2.85 \\
\hline E10C25 & 83 & 28.6 & 38.8 & 2.9 & 4.25 & 2.6 & 2.85 \\
\hline E10C30 & 81 & 29.6 & 39.2 & 2.9 & 4.25 & 2.7 & 2.85 \\
\hline E10C35 & 78 & 25.8 & 38.3 & 3.2 & 4.25 & 2.82 & 2.9 \\
\hline E10C40 & 80 & 19.2 & 27.3 & 3.2 & 4.25 & 2.82 & 2.9 \\
\hline E10C45 & 80 & 16.5 & 24.6 & 3.2 & 4.30 & 2.82 & 3 \\
\hline
\end{tabular}

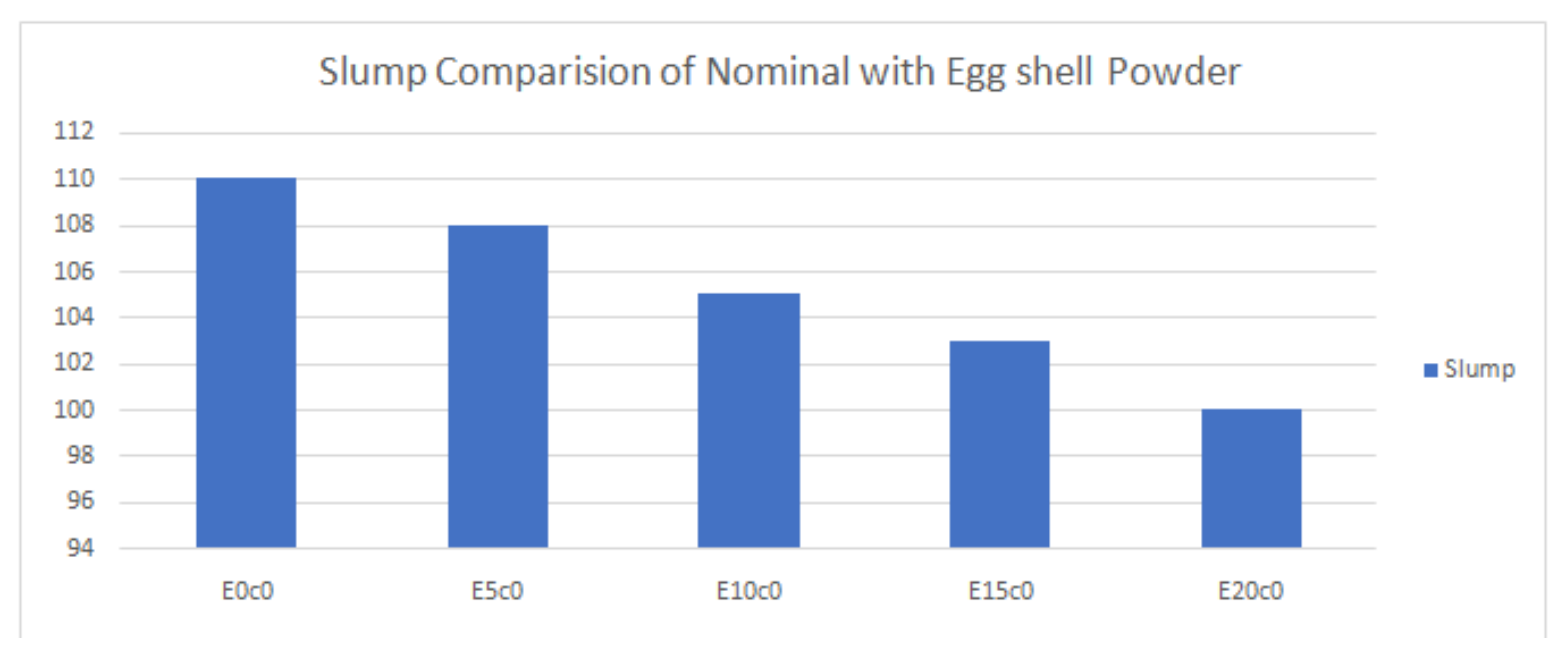

Figure 3: Slump Comparison of Nominal with Eggshell Powder. 


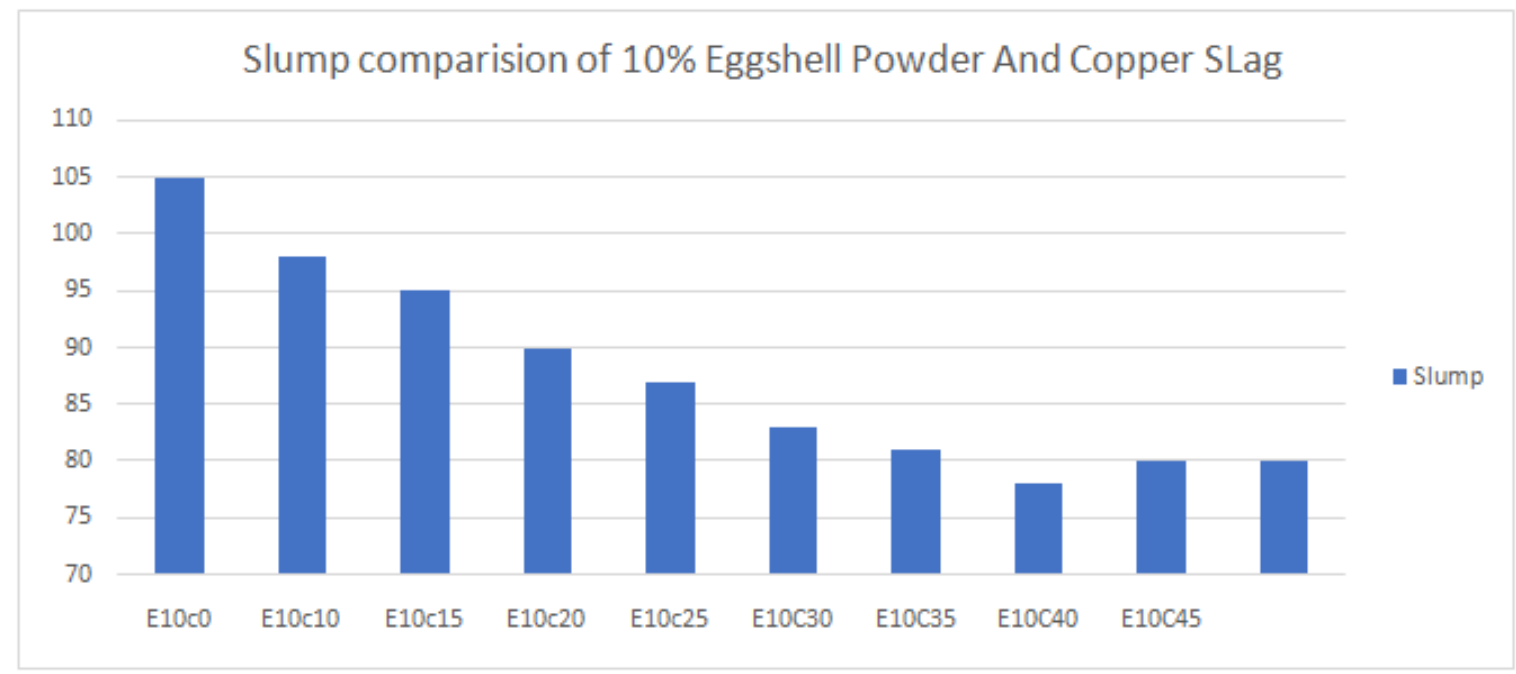

Figure 4: Slump comparison of $\mathbf{1 0 \%}$ Eggshell Powder and Copper Slag.

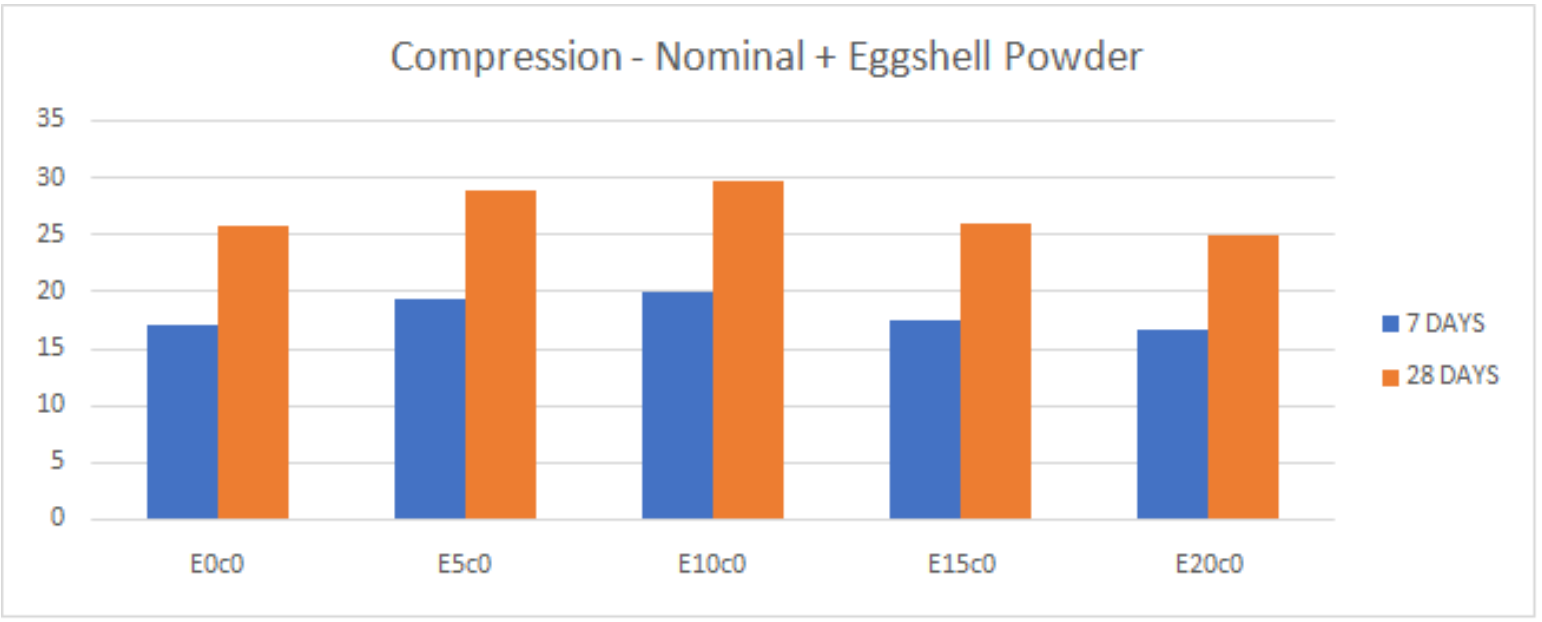

Figure 5: Compression Strength - Nominal + Eggshell Powder.

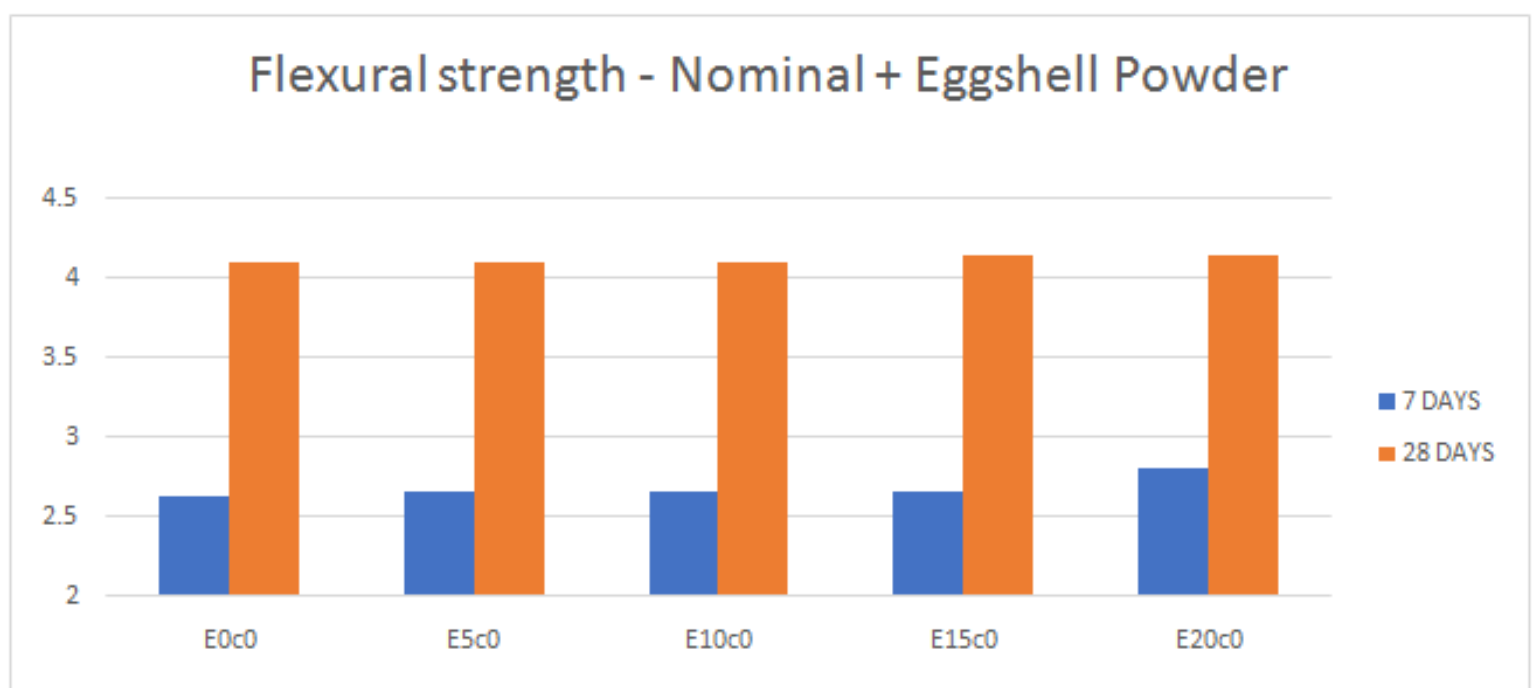

Figure 6: Flexural Strength - Nominal + Eggshell Powder. 


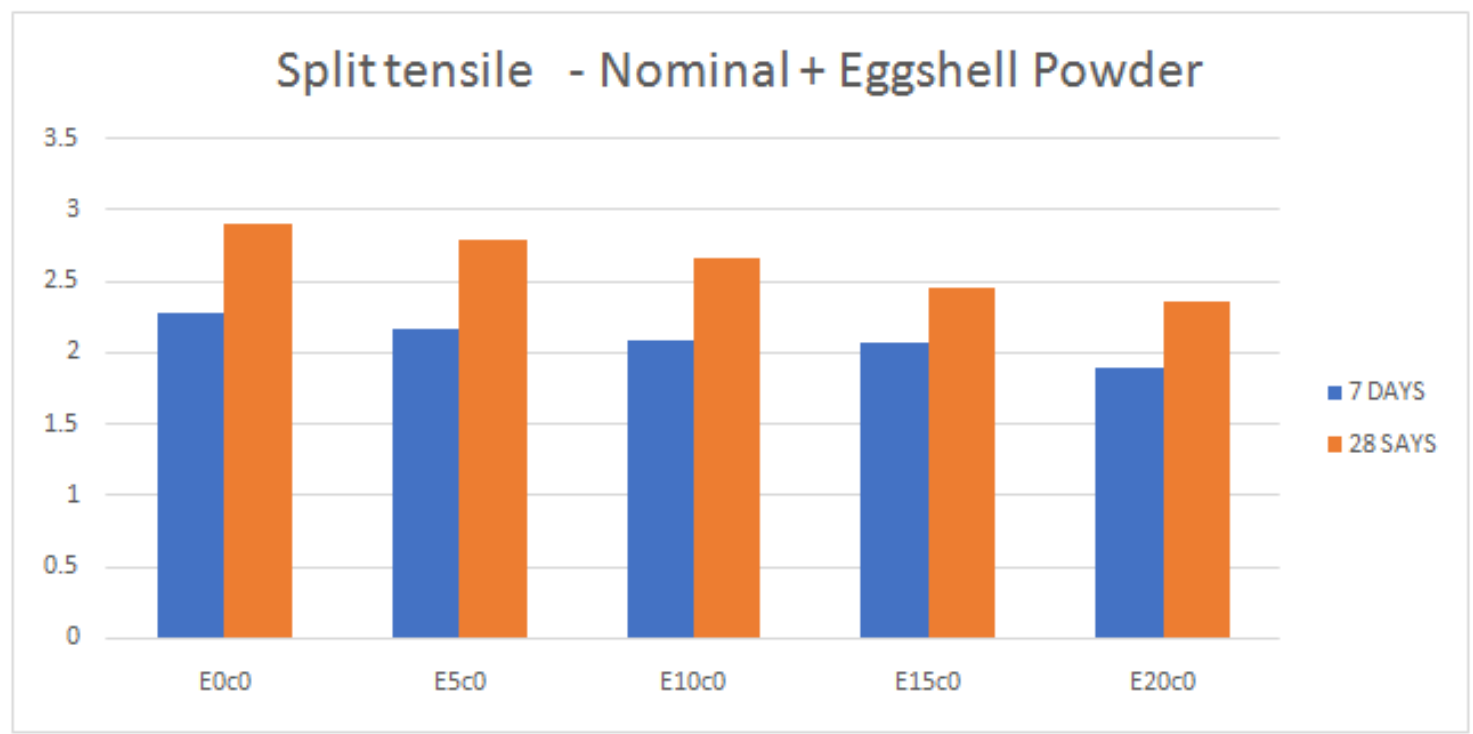

Figure 7: Split Tensile Strength - Nominal + Eggshell Powder.

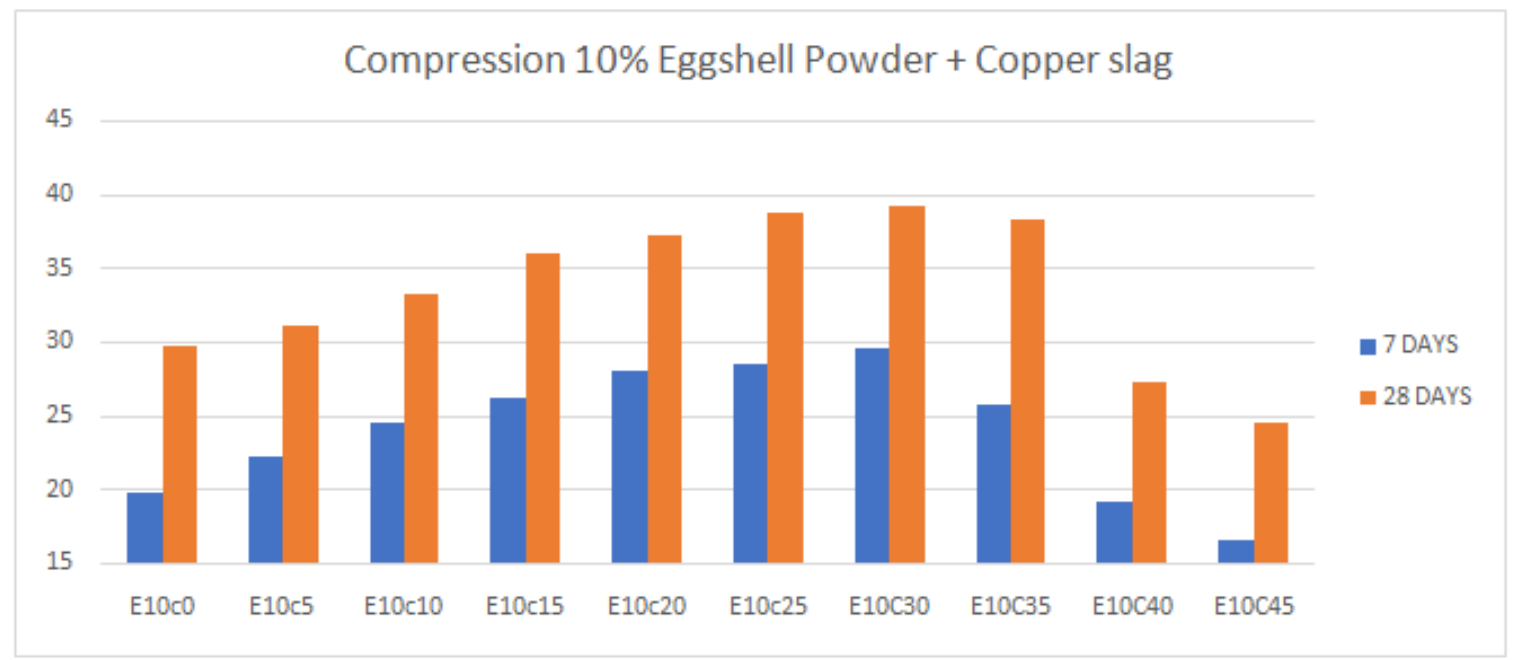

Figure 8: Compression Strength - 10\% Eggshell Powder + Copper Slag.

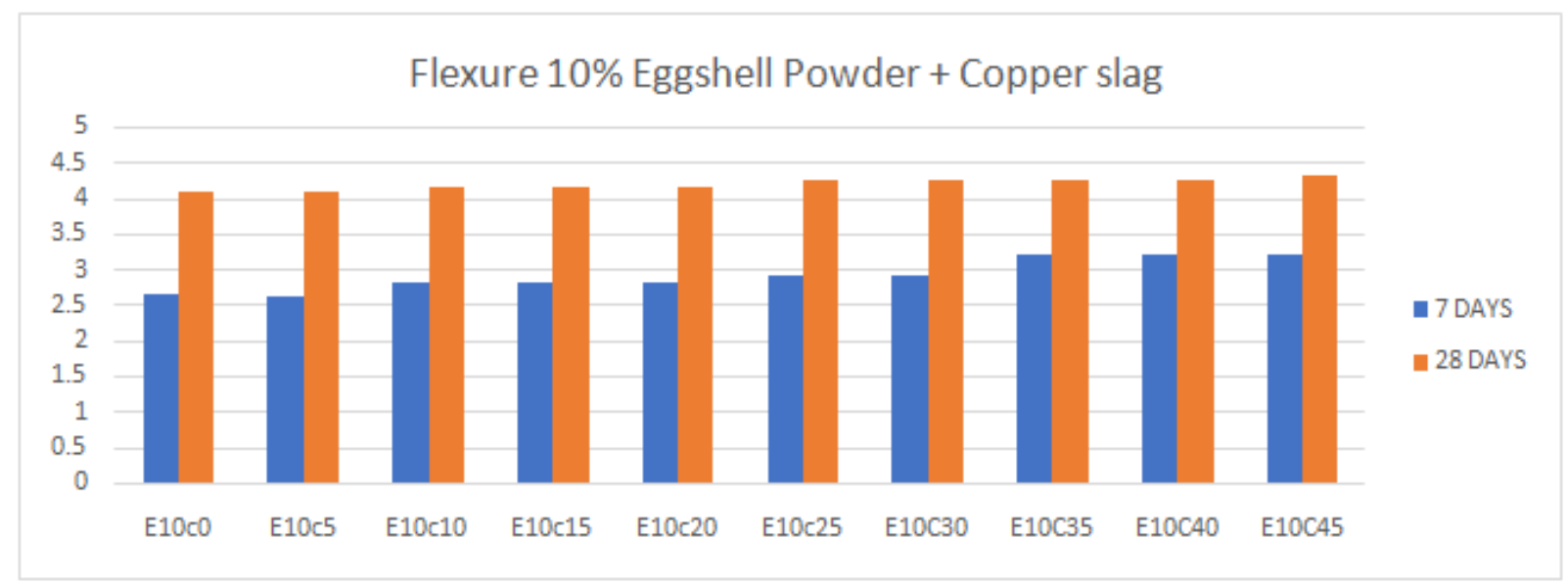

Figure 9: Flexure Strength - 10\% Eggshell Powder + Copper Slag. 


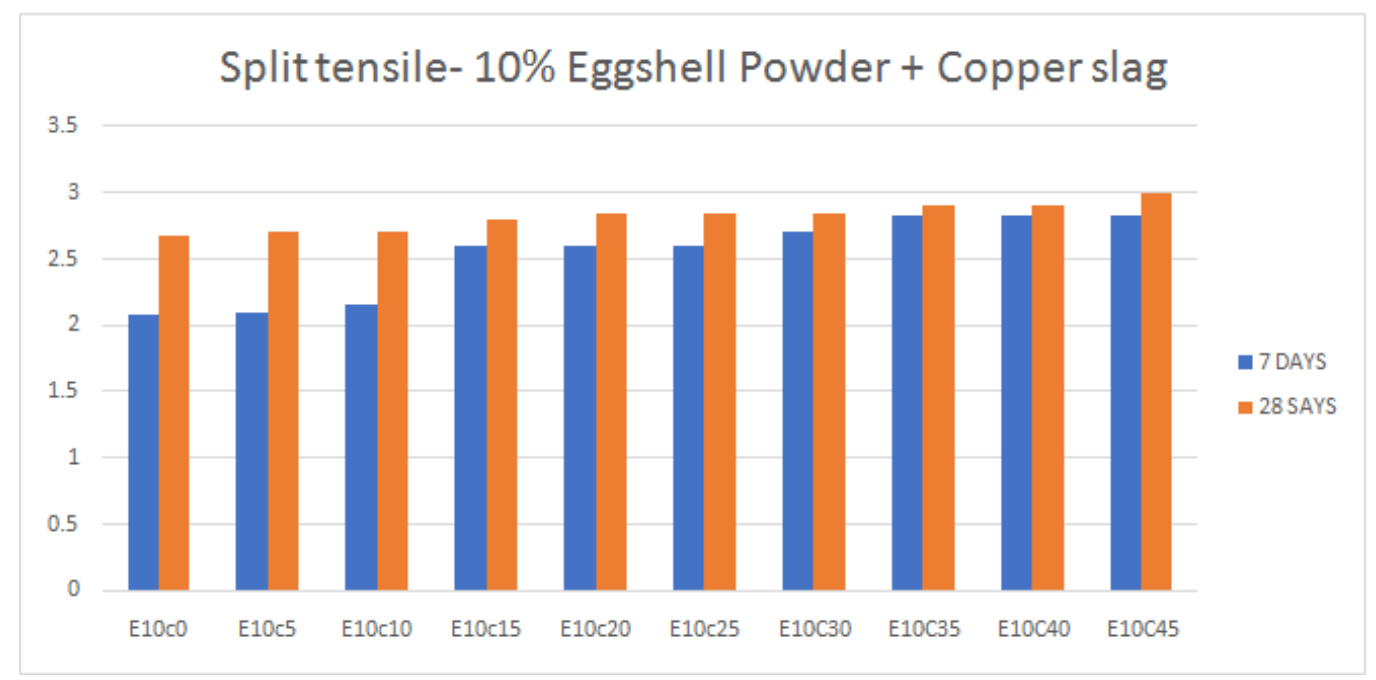

Figure 10: Split Tensile Strength - 10\% Eggshell Powder + Copper Slag.

\section{CONCLUSIONS}

- Eggshell powder and copper slag can be a good replacement in a concrete mix.

- The eggshell powder can only be used were compression is the governing factor.

- Cement can be replaced $10 \%$ by eggshell powder for optimum result.

- $15 \%$ of cement can be replaced without losing the compressive strength it is not good for flexure and split tensile strength.

- Copper slag can replace a maximum $40 \%$ fine aggregate without losing the strength and $30 \%$ replacement can be done for optimum results.

- A good reduction in cost can also be seen at this \% of replacements.

\section{REFERENCES}

1. A. Kumar, "Egg Shell Powder Partial Replaced With Cement Concrete," Int. J. Sci. Res., Vol. 7, No. 9, pp. 2016-2019, 2018, doi: 10.21275/ART20191098.

2. M. V Patil, "PROPERTIES AND EFFECTS OF COPPER SLAG IN CONCRETE Aggregate:," Int. J. Adv. Mech. Civ. Eng., No. 2, pp. 46-50, 2015.

3. A. K. Tiwary and prince, "Use of Copper Slag as Fine Aggregate in Concrete :," Int. J. Res. Appl. Sci. Eng. Technol., Vol. 6, No. Ii, pp. 2224-2230, 2018.

4. B. Divya, K. Vasanthavalli, and R. Ambalavanan, "Investigation on Cement Concrete at Mixed With Egg Shell Powder," Int. J. Innov. Res. Sci. Eng. Technol., pp. 3946-3950, 2017, doi: 10.15680/IJIRSET.2017.0603167.

5. S. A. Raji and A. T. Samuel, "Egg Shell As A Fine Aggregate In Concrete For Sustainable Construction," Int. J. Sci. Technol. Res. Vol., Vol. 4, No. 09, pp. 8-13, 2015.

6. IS 10262:2019, “Concrete Mix Proportioning - Guidelines," Indian Stand., No. January, 2019.

7. IS 516:1959, "Methods of Tests for Strength of Concrete," 1959.

8. IS 5816:1999, "Splitting Tensile Strength of Concrete- Method of Test," Indian Stand., 1999. 
9. IS 456:2000, “Plain and Reinforced Concrete - Code of Practice," Indian Stand., No. July, 2000.

10. N. Gupta and R. Siddique, "Durability characteristics of self-compacting concrete made with copper slag," Constr. Build. Mater., Vol. 247, p. 118580, 2020, doi: 10.1016/j.conbuildmat.2020.118580.

11. S. Geetha and S. Madhavan, "High Performance Concrete with Copper slag for Marine Environment," Mater. Today Proc., Vol. 4, No. 2, pp. 3525-3533, 2017, doi: 10.1016/j.matpr.2017.02.243.

12. A. Rajasekar, K. Arunachalam, and M. Kottaisamy, "Assessment of Strength and Durability Characteristics of Copper," J. Clean. Prod., 2018, doi: 10.1016/j.jclepro.2018.10.118.

13. C. Shi, C. Meyer, and A. Behnood, "Resources, Conservation and Recycling Utilization of copper slag in cement and concrete," Resour. Conserv. Recycl., Vol. 52, pp. 1115-1120, 2008, doi: 10.1016/j.resconrec.2008.06.008.

14. C. K. Madheswaran, P. S. Ambily, J. K. Dattatreya, and N. P. Rajamane, "Studies on use of Copper Slag as Replacement Material for River Sand in Building Constructions," Vol. 95, No. September, pp. 169-177, 2014, doi: 10.1007/s40030-0140084-9.

15. J. Karthick, R. Jeyanthi, and M. Petchiyammal, "Experimental Study on Usage of Egg Shell as Partial Replacement for Sand in Concrete," Int. J. Adv. Res. Educ. Technol., Vol. 1, No. 1, pp. 7-10, 2014.

16. H. Bhaskaran, L. John, P. M. Neethu, and T. Sebastian, “Study on Egg Shell Concrete," Int. J. Eng. Res. Technol., Vol. 4, No. 13, pp. 4-6, 2016.

17. A. Brahimi, M. Meghachou, and H. Abbad, "Analysis of experimental data of environmental cement prepared by fly ash of eggs shell and sand dune for reduction of carbon dioxid," Data Br., p. 105407, 2020, doi: 10.1016/j.dib.2020.105407.

18. V. Gokulnath, B. Ramesh, and S. S. Reddy, "Proceedings Addition of reinforcing materials in self compacting concrete," Mater. Today Proc., no. xxxx, 2019, doi: 10.1016/j.matpr.2019.10.013.

19. IS: 8112- 2013, “Ordinary Portland Cement, 43 Grade," Indian Stand., no. March, 2013.

20. H. Y. Tiong, S. K. Lim, Y. L. Lee, C. F. Ong, and M. K. Yew, "Environmental impact and quality assessment of using eggshell powder incorporated in lightweight foamed concrete," Constr. Build. Mater., Vol. 244, p. 118341, 2020, doi: 10.1016/j.conbuildmat.2020.118341.

21. S. M. Hama, "Improving Mechanical Properties of Lightweight Porcelanite Aggregate Concrete Using Different Waste Material,” Int. J. Sustain. Built Environ., 2017, doi: 10.1016/j.ijsbe.2017.03.002.

22. A. Parkash and P. Yadav, “A REVIEW STUDY OF EGG SHELL POWDER AS A CEMENT REPLACING,” Int. J. Latest Res. Eng. Comput., Vol. 5, No. 4, pp. 28-31, 2017.

23. Dinesh, K. "Analysis of Mechanical Strength for Nanosized Scandia Doped Dispenser Cathodes." International Journal of Mechanical and Production Engineering Research and Development (IJMPERD) 8.1 (2018):803-806

24. Salawu, Enesi Y., and Oluseyi O. Ajayi. "Micro-Structural and Mechanical Characterization of Pulverized Wood Charcoal and Egg-Shell as Organic Carbon Additives for Grey Cast Iron Carburization." International Journal of Mechanical and Production Engineering Research and Development (IJMPERD) 9.6 (2019):391-398

25. Hussein, Ammar Fadhil. "Effect of UV-Radiation on Fatigue Behaviour of Natural Composite Materials." International Journal of Mechanical and Production Engineering Research and Development (IJMPERD) 8.4 (2018):727-740

26. Alam, Mehtab, et al. "Acceptability of demolished concrete waste aggregate in making high strength self-compacting concrete." International Journal of Civil Engineering (IJCE) 2.3 (2013): 1-12. 